\title{
Synthesis and Biological Evaluation of the novel Antioxidant Agent
}

\section{Quercetin Derivatives}

$$
\begin{aligned}
& \text { Xin } \mathrm{Qu}^{1, \mathrm{a}}, \quad \text { Hongye Zhao }{ }^{1, \mathrm{~b}}, \quad \text { Dan } \mathrm{Wu}^{1, \mathrm{c}} \text {, Lianbo Zhao }{ }^{1, \mathrm{~d}}, \mathrm{Kui} \mathrm{Lu}^{1, \mathrm{e}} \text {, and Yuou } \\
& \text { Teng }^{1, f^{*}}
\end{aligned}
$$

${ }^{1}$ Key Lab of Industrial Fermentation Microbiology, Tianjin Key Lab of Industrial Microbiology, Tianjin University of Science and Technology, Tianjin, P. R. China

a quxin0616@163.com, b zhaohongye610@126.com, cwudan2013126@126.com, d zhaolianbo123456@126.com, elukui@tust.edu.cn ,tyo201485@tust.edu.cn

Keywords: Quercetin, PC-12 cells, Antioxidant Activity

Abstract. Three 3-substituted derivatives of quercetin were synthesized in 10-80\% overall yields. Their structures were characterized by ${ }^{1}$ HNMR. Three target compounds (4a $\left.4 \mathbf{c}\right)$ have not been reported before. The results showed that: pre-treated of PC-12 cells with, cell survival rate was higher than that of quercetin. In this project, the oxidative damage model of PC-12 cells was established and the antioxidant activities of three newly synthesized quercetin derivatives were evaluated. Among them, compound $\mathbf{4 b}(30 \mu \mathrm{M})$ showed the highest antioxidant activity against $\mathrm{H}_{2} \mathrm{O}_{2}$. Cell viability in pre-treated with or without compound $4 \mathbf{b}(30 \mu \mathrm{M})$ were $53.05 \%$ and $10.31 \%$, higher than that of quercetin $(47.22 \%)$.

\section{Introduction}

Oxidative stress has been considered as a major cause of cellular injuries in a variety of clinical abnormalities ${ }^{[1]}$.Flavonoids are polyphenolic compounds that occur ubiquitously in foods of plant origin $^{[2]}$.Quercetin $\left(3,3^{\prime}, 4^{\prime}, 5,7\right.$-pentahydroxy flavone, quercetin) is a grown-derived flavonoids, widely found in herbal and food ${ }^{[3-5]}$. Quercetin displays antioxidant, anti-inflammatory, anti-metastatic and anticancer activities ${ }^{[6-12]}$.

In this paper, we would like to report the design and a convenient synthetic approach towards a novel series of 3-substituted derivatives of quercetin. The antioxidant activities of target compounds $(\mathbf{4 a} \sim \mathbf{4} \mathbf{c})$ were evaluated by MTT assay in the oxidative damage model of PC-12 cells.

\section{EXPERIMENTAL SECTION}

\section{Materials and measurements}

Used in this article, all reagents and solvents were of analytical grade. The reaction temperature control uses the oil bath temperature modulator. Thin layer chromatography (TLC) with silica gel 60 GF254. Merck precoated plates $(0.25 \mathrm{~mm})$ was visualized using UV. 0.1 for flash chromatography on silica gel (particle size 100-200 mesh). ${ }^{1} \mathrm{H}$ spectra were recorded in DMSO on Bruker AM-400 NMR spectrometers using tetramethylsilane (TMS) as an internal standard. The chemical shifts are reported in $\delta(\mathrm{ppm})$ relative to tetramethylsilane as internal standard 


\section{Synthesis route of Quercetin derivative}

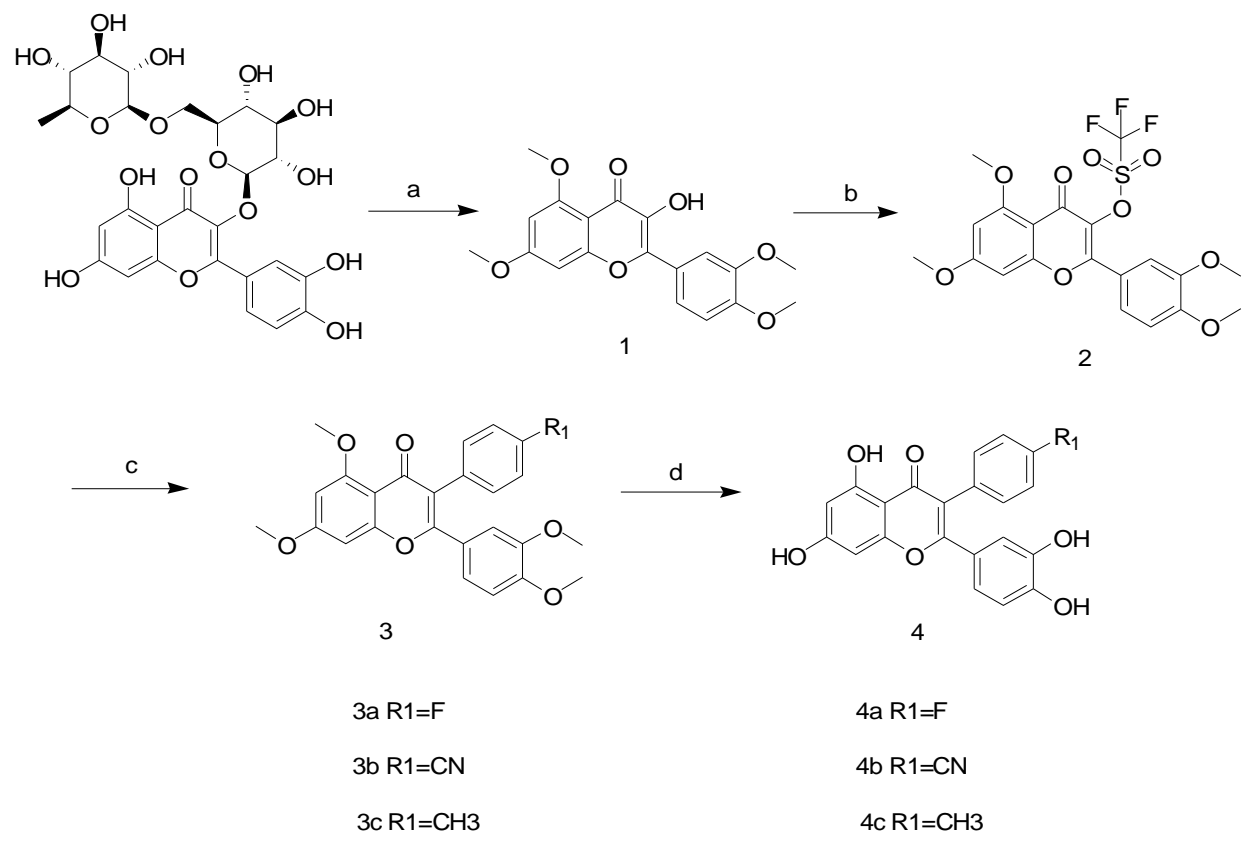

Fig 1 synthesis route of quercetin derivatives

Reagents and conditions: (a) $\mathrm{CH}_{3} \mathrm{I}, \mathrm{K}_{2} \mathrm{CO}_{3}$, DMF, rt. $2 \% \mathrm{H}_{2} \mathrm{SO}_{4}, 95^{\circ} \mathrm{C}$; (b) $\mathrm{PhN}(\mathrm{Tf})_{2}, \mathrm{~K}_{2} \mathrm{CO}_{3}$, THF, rt;(c) DMF, $\mathrm{CS}_{2} \mathrm{CO}_{3}, \mathrm{PdCl}_{2}$ (dppf), $90^{\circ} \mathrm{C}$; (d)DCM, $\mathrm{BBr}_{3},-30{ }^{\circ} \mathrm{C}$.

Synthesis of 2-(3,4-dimethoxyphenyl)-3-hydroxy-5,7-dimethoxy-4H-chromen-4-one (compound 1)

Rutin $(5.00 \mathrm{~g})$ in $30 \mathrm{~mL}$ DMF was added $\mathrm{K}_{2} \mathrm{CO}_{3}(5.66 \mathrm{~g}, 40.95 \mathrm{mmol})$ and iodomethane $(2.5 \mathrm{~mL}$, $40.95 \mathrm{mmol})$. The reaction mixture was stirred at room temperature for $10 \mathrm{~h}$. Then solvent was removed under reduced pressure. $250 \mathrm{~mL} 2 \% \mathrm{H}_{2} \mathrm{SO}_{4}$ was added to the residue and then reflux for 3 $\mathrm{h}$. The reaction mixture was filtered and the filter cake was purified by silica gel chromatography using PE:EA (1:1) as the eluent to afford compound 1. (2.075 g, $71 \%$ )

Synthesis of 2-(3,4-dimethoxyphenyl)-5,7-dimethoxy-4-oxo-4H-chromen-3-yl trifluoromethanesulfonate (compound 2)

Compound $1(2.79 \mathrm{~g})$ in $10 \mathrm{~mL}$ THF was added $\mathrm{K}_{2} \mathrm{CO}_{3}(0.771 \mathrm{~g}, 5.58 \mathrm{mmol})$ and N-phenyl-bis trifluoromethanesulfonimide $(1.50 \mathrm{~g}, 4.19 \mathrm{mmol})$. The reaction mixture was stirred at room temperature for $10 \mathrm{~h}$. Then the reaction was poured into $20 \mathrm{~mL}$ of ice water and extracted the mixture with dichloromethane. The reaction mixture was filtered and the filter cake was purified by silica gel chromatography using PE:EA (4:1) as the eluent to afford compound 2 . ( $1 \mathrm{~g}, 73 \%$ )

Synthesis of 2-(3,4-dimethoxyphenyl)-3-(4-fluorophenyl)-5,7-dimethoxy-4H-chromen-4-one (compound 3a)

Compound $2(0.2 \mathrm{~g}, 0.4 \mathrm{mmol})$ in $3 \mathrm{~mL}$ DMF was added $\mathrm{Cs}_{2} \mathrm{CO}_{3}(186 \mathrm{mg}, 0.56 \mathrm{mmol})$, 4-Methylphenylboronic acid $(77 \mathrm{mg}, 0.56 \mathrm{mmol})$ and $\mathrm{PdCl}_{2}(\mathrm{dppf})(30 \mathrm{mg}, 0.04 \mathrm{mmol})$. The reaction mixture was stirred at $90^{\circ} \mathrm{C}$ for $5 \mathrm{~h}$. Then the reaction was poured into $10 \mathrm{~mL}$ of ice water and extracted the mixture with dichloromethane three times. The combined organic layers were dried over $\mathrm{Na}_{2} \mathrm{SO}_{4}$ to give a residue which was purified by silica gel chromatography using PE:EA(2:1) as the eluent to afford the title compound $3 \mathbf{a}(105 \mathrm{mg}, 59 \%)$.

Synthesis of 4-(2-(3,4-dimethoxyphenyl)-5,7-dimethoxy-4-oxo-4H-chromen-3-yl)benzonitrile (compound 3b)

Compound $2(0.2 \mathrm{~g}, 0.4 \mathrm{mmol})$ in $3 \mathrm{~mL}$ DMF was added $\mathrm{Cs}_{2} \mathrm{CO}_{3}(186 \mathrm{mg}, 0.56 \mathrm{mmol})$, 4-Cyanophenylboronic acid $(84 \mathrm{mg}, 0.56 \mathrm{mmol})$ and $\mathrm{PdCl}_{2}(\mathrm{dppf})(30 \mathrm{mg}, 0.04 \mathrm{mmol})$. The reaction 
mixture was stirred at $90^{\circ} \mathrm{C}$ for $5 \mathrm{~h}$. Then the reaction was poured into $10 \mathrm{~mL}$ of ice water and extracted the mixture with dichloromethane three times. The combined organic layers were dried over $\mathrm{Na}_{2} \mathrm{SO}_{4}$ to give a residue which was purified by silica gel chromatography using PE:EA $(2: 1)$ as the eluent to afford the title compound $\mathbf{3 b}(125 \mathrm{mg}, 69 \%)$.

Synthesis of 2-(3,4-dimethoxyphenyl)-5,7-dimethoxy-3-(p-tolyl)-4H-chromen-4-one (compound 3c)

Compound 2 ( $0.2 \mathrm{~g}, 0.4 \mathrm{mmol})$ in $3 \mathrm{~mL}$ DMF was added $\mathrm{Cs}_{2} \mathrm{CO}_{3}(186 \mathrm{mg}, 0.56 \mathrm{mmol})$, 4-Fluorophenylboronic Acid (80 mg ,0.56 mmol) and $\mathrm{PdCl}_{2}(\mathrm{dppf})(30 \mathrm{mg}, 0.04 \mathrm{mmol})$. The reaction mixture was stirred at $90^{\circ} \mathrm{C}$ for $5 \mathrm{~h}$. Then the reaction was poured into $10 \mathrm{~mL}$ of ice water and extracted the mixture with dichloromethane three times. The combined organic layers were dried over $\mathrm{Na}_{2} \mathrm{SO}_{4}$ to give a residue which was purified by silica gel chromatography using PE:EA (2:1) as the eluent to afford the title compound $\mathbf{3 c}(130 \mathrm{mg}, 73 \%)$.

Synthesis of 2-(3,4-dihydroxyphenyl)-3-(4-fluorophenyl)-5,7-dihydroxy-4H-chromen-4-one (compound 4a)

To a solution of compound 3a $(40 \mathrm{mg})$ in DCM $(3 \mathrm{ml})$ was added $\mathrm{BBr}_{3}(0.15 \mathrm{ml})$ below $-30{ }^{\circ} \mathrm{C}$. After complete addition, the reaction was warmed to room temperature and stirred for $5 \mathrm{~h}$. The reaction mixture was quenched with methanol. Further purification was performed with silica gel chromatography using PE:EA (1:1) as the eluent to afford the title compound $\mathbf{4 a}(15 \mathrm{mg}, 50 \%)$.

Synthesis of 4-(2-(3,4-dihydroxyphenyl)-5,7-dihydroxy-4-oxo-4H-chromen-3-yl)benzonitrile (compound 4b)

To a solution of compound $\mathbf{3 b}(50 \mathrm{mg})$ in $\mathrm{DCM}$ was added $\mathrm{BBr}_{3}(0.15 \mathrm{ml})$ below $-30{ }^{\circ} \mathrm{C}$. After complete addition, the reaction was warmed to room temperature and stirred for $5 \mathrm{~h}$. The reaction mixture was quenched with methanol. Further purification was performed with silica gel chromatography using PE:EA (1:1) as the eluent to afford the title compound $\mathbf{4 b}(5.22 \mathrm{mg}, 12 \%)$.

\section{Synthesis of 2-(3,4-dihydroxyphenyl)-5,7-dihydroxy-3-(p-tolyl)-4H-chromen-4-one (compound 4c)}

To a solution of compound $3 \mathbf{c}(100 \mathrm{mg})$ in $\mathrm{DCM}$ was added $\mathrm{BBr}_{3}(0.2 \mathrm{ml})$ below $-30{ }^{\circ} \mathrm{C}$. After complete addition, the reaction was warmed to room temperature and stirred for $5 \mathrm{~h}$. The reaction mixture was quenched with methanol. Further purification was performed with silica gel chromatography using PE:EA (1:1) as the eluent to afford the title compound $\mathbf{4 c}(32.32 \mathrm{mg}, 37 \%)$.

\section{Biological assay}

In this project, the oxidative damage model of PC-12 cells was established and the antioxidant activities of three newly synthesized quercetin derivatives were evaluated MTT assay. In the oxidative damage model, the cell viability was evaluated by MTT assay to reflect the antioxidant activity against $\mathrm{H}_{2} \mathrm{O}_{2}$. Brifly, $90 \mu \mathrm{l}$ of the PC- 12 cells were plated in 96-well plates at a density of 5 $\times 10^{4}$ cells per well and cultured at $37^{\circ} \mathrm{C}$ in $5 \% \mathrm{CO}_{2}$ for $16 \mathrm{~h}$. Cells were treated with different concentrations of compounds and incubated at $37{ }^{\circ} \mathrm{C}$ for an additional $0.5 \mathrm{~h}$ then $\mathrm{H}_{2} \mathrm{O}_{2}(100 \mu \mathrm{M})$ was added to the medium for $2 \mathrm{~h}$. MTT assay(the cell viability) was performed using Thermo microplate reader.

\section{RESULTS AND DISCUSSION}

Characterize isatin derivatives by ${ }^{1} \mathrm{H}$ NMR.

2-(3,4-dimethoxyphenyl)-5,7-dimethoxy-4-oxo-4H-chromen-3-yl trifluoromethanesulfonate (2)

${ }^{1} \mathrm{H}$ NMR $\left(d_{6}\right.$-DMSO $\left.400 \mathrm{MHz}\right): \delta / \mathrm{ppm} 3.84(\mathrm{~s}, 3 \mathrm{H}), 3.87$ (s, 3H), $3.90(\mathrm{~s}, 3 \mathrm{H}), 3.93(\mathrm{~s}, 3 \mathrm{H}), 6.63(\mathrm{~d}$, $J=2.0 \mathrm{~Hz}, 1 \mathrm{H}), 6.90(\mathrm{~d}, J=6.0 \mathrm{~Hz}, 1 \mathrm{H}), 7.19(\mathrm{~d}, J=8.4 \mathrm{~Hz}, 1 \mathrm{H}), 7.44(\mathrm{~d}, J=2.0 \mathrm{~Hz}, 1 \mathrm{H}), 7.49(\mathrm{t}, J$ 
$=6.8 \mathrm{~Hz}, 1 \mathrm{H})$

2-(3,4-dimethoxyphenyl)-3-(4-fluorophenyl)-5,7-dimethoxy-4H-chromen-4-one (3a)

${ }^{1} \mathrm{H}$ NMR $\left(\mathrm{CDCl}_{3} 400 \mathrm{MHz}\right): \delta / \mathrm{ppm} 2.32(\mathrm{~s}, 3 \mathrm{H}), 3.48(\mathrm{~s}, 3 \mathrm{H}), 3.80(\mathrm{~s}, 3 \mathrm{H}), 3.91(\mathrm{~s}, 3 \mathrm{H}), 3.93$ (s, $3 \mathrm{H}), 6.37(\mathrm{~d}, J=1.6 \mathrm{~Hz}, 1 \mathrm{H}), 6.53(\mathrm{~d}, J=2.0 \mathrm{~Hz}, 1 \mathrm{H}), 6.68(\mathrm{~d}, J=2.0 \mathrm{~Hz}, 1 \mathrm{H}), 6.80(\mathrm{~d}, J=8.4 \mathrm{~Hz}$,

$1 \mathrm{H}), 7.11(\mathrm{~s}, 4 \mathrm{H}) 7.21(\mathrm{dd}, J=2.0,8.4 \mathrm{~Hz}, 1 \mathrm{H})$

4-(2-(3,4-dimethoxyphenyl)-5,7-dimethoxy-4-oxo-4H-chromen-3-yl)benzonitrile (3b)

${ }^{1} \mathrm{H}$ NMR (CDCl $\left.400 \mathrm{MHz}\right): \delta / p p m 3.60$ (s, 3H), 3.89 (s, 3H), 3.93 (s, 3H), $3.94(\mathrm{~s}, 3 \mathrm{H}), 6.40$ (d, $J$ $=2.0 \mathrm{~Hz}, 1 \mathrm{H}), 6.55(\mathrm{~d}, J=2.0 \mathrm{~Hz}, 1 \mathrm{H}), 6.72(\mathrm{~d}, J=1.6 \mathrm{~Hz}, 1 \mathrm{H}), 6.78(\mathrm{~d}, J=8.4 \mathrm{~Hz}, 1 \mathrm{H}), 7.02(\mathrm{dd}$, $J=2.0,8.4 \mathrm{~Hz}, 1 \mathrm{H}), 7.37(\mathrm{~d}, J=8.4 \mathrm{~Hz}, 2 \mathrm{H}), 7.59(\mathrm{~d}, J=8.0 \mathrm{~Hz}, 2 \mathrm{H})$

2-(3,4-dimethoxyphenyl)-5,7-dimethoxy-3-(p-tolyl)-4H-chromen-4-one (3c)

${ }^{1} \mathrm{H}$ NMR $\left(\mathrm{CDCl}_{3} 400 \mathrm{MHz}\right): \delta / \mathrm{ppm} 3.57(\mathrm{~s}, 3 \mathrm{H}), 3.89(\mathrm{~s}, 3 \mathrm{H}), 3.92(\mathrm{~s}, 3 \mathrm{H}), 3.93(\mathrm{~s}, 3 \mathrm{H}), 6.38(\mathrm{~d}, J$ $=2.0 \mathrm{~Hz}, 1 \mathrm{H}), 6.54(\mathrm{~d}, J=2.4 \mathrm{~Hz}, 1 \mathrm{H}), 6.71(\mathrm{~d}, J=2.0 \mathrm{~Hz}, 1 \mathrm{H}), 6.80(\mathrm{~d}, J=8.4 \mathrm{~Hz}, 1 \mathrm{H}), 7.00(\mathrm{t}, J$ $=8.8 \mathrm{~Hz}, 2 \mathrm{H}), 7.14(\mathrm{dd}, J=2.0,8.4 \mathrm{~Hz}, 1 \mathrm{H}), 7.19-7.23(\mathrm{~m}, 2 \mathrm{H})$ (4a)

Synthesis of 2-(3,4-dihydroxyphenyl)-3-(4-fluorophenyl)-5,7-dihydroxy-4H-chromen-4-one

${ }^{1} \mathrm{H}$ NMR (400 MHz, DMSO) $\delta 13.03$ (s, 1H), 10.84 (s, 1H), 9.57 (s, 1H), 9.12 (s, 1H), 7.13 (d, $J=$ $7.8 \mathrm{~Hz}, 2 \mathrm{H}), 7.05(\mathrm{~d}, J=7.5 \mathrm{~Hz}, 2 \mathrm{H}), 6.84(\mathrm{~s}, 1 \mathrm{H}), 6.61(\mathrm{~s}, 2 \mathrm{H}), 6.40(\mathrm{~s}, 1 \mathrm{H}), 6.21(\mathrm{~s}, 1 \mathrm{H}), 2.31(\mathrm{~s}$, $3 \mathrm{H})$. (4b)

Synthesis of 4-(2-(3,4-dihydroxyphenyl)-5,7-dihydroxy-4-oxo-4H-chromen-3-yl)benzonitrile

${ }^{1} \mathrm{H}$ NMR (400 MHz, DMSO) $\delta 12.81(\mathrm{~s}, 1 \mathrm{H}), 10.92(\mathrm{~s}, 1 \mathrm{H}), 9.65(\mathrm{~s}, 1 \mathrm{H}), 9.22(\mathrm{~s}, 1 \mathrm{H}), 7.80(\mathrm{~d}, J=$ $7.9 \mathrm{~Hz}, 2 \mathrm{H}), 7.40$ (d, J=7.9 Hz, 2H), $6.78(\mathrm{~s}, 1 \mathrm{H}), 6.64(\mathrm{~s}, 2 \mathrm{H}), 6.43(\mathrm{~s}, 1 \mathrm{H}), 6.24(\mathrm{~s}, 1 \mathrm{H})$.

Synthesis of 2-(3,4-dihydroxyphenyl)-5,7-dihydroxy-3-(p-tolyl)-4H-chromen-4-one (4c)

${ }^{1} \mathrm{H}$ NMR (400 MHz, DMSO) $\delta 12.95$ (s, 1H), 10.86 (s, 1H), 9.59 (s, 1H), 9.16 (s, 1H), 7.26 - 7.13 (m, 4H), $6.81(\mathrm{~s}, 1 \mathrm{H}), 6.63(\mathrm{~s}, 2 \mathrm{H}), 6.41(\mathrm{~d}, J=1.9 \mathrm{~Hz}, 1 \mathrm{H}), 6.22(\mathrm{~d}, J=2.0 \mathrm{~Hz}, 1 \mathrm{H})$.

Antioxidant activity assay.

The newly prepared 3-substituted derivatives of quercetin were evaluated for their in vitro cytotoxic effects against PC-12 cells by the standard MTT assay with VC as the positive control. The preliminary results were summarized in Table 1.

Table 1 The cell viability of $\mathrm{PC}-12$ treated with $\mathrm{H}_{2} \mathrm{O}_{2}$ and 3-substituted quercetin derivatives

$$
\mathrm{H}_{2} \mathrm{O}_{2}
$$

\begin{tabular}{cccccccc}
\cline { 3 - 7 } Compond & DMSO & DMSO & $4 \mathrm{a}$ & $4 \mathrm{~b}$ & $4 \mathrm{c}$ & quercetin & VC \\
\hline Cell viability (\%) & 100.00 & 10.31 & 32.21 & 53.05 & 17.27 & 47.22 & 65.26 \\
\hline
\end{tabular}

\section{Conclusion}

Biological activity test indicated that: compound $\mathbf{4 b}(30 \mu \mathrm{M})$ showed the highest antioxidant activity against $\mathrm{H}_{2} \mathrm{O}_{2}$. Cell viability in pre-treated with or without compound $\mathbf{4 b}(30 \mu \mathrm{M})$ were $53.05 \%$ and $10.31 \%$, higher than that of quercetin $(47.22 \%)$.

\section{Acknowledgment}

The authors sincerely thank the financial support from National Natural Science Foundation of China (31301142) and International Science \& Technology Cooperation Program of China 
(2013DFA31160).

\section{REFERENCES}

[1]Lu YH, Su MY, Huang HY, Lin-Li, Yuan CG. Protective effects of the citrus flavanones to PC12 cells against cytotoxicity induced by hydrogen peroxide. Neurosci Lett. 2010,Oct 22;484(1):6-11.

[2]Hollman PC, Katan MB. Dietary flavonoids: intake, health effects and bioavailability. Food and Chemical Toxicology. September-October 1999, Pages 937-942

[3] Crystal S, Kevin A L, Ellen B P, et al. Genetic analysis of quercetin in onion (Allium cepa L.)[ J]. Journal of Agriculture and Natural. Resource, 2003, 16(1): 24-28.

[4] Saw C L L, Guo Y, Yang A Y, et al. The berry constituents quercetin, kaempferol, and pterostilbene synergistically attenuate reactive oxygen species: Involvement of the Nrf2-ARE signaling pathway[J]. Food and Chemical Toxicology, 2014, 72: 303-311.

[5]Mitchell AE, Hong YJ, Koh E, et al. Ten-year comparison of the influence of organic and conventional crop management practices on the content of flavonoids in tomatoes[ J]. J Agric Food Chem, 2007, 55(15): 6154-6159

[6]Gibellini L, Pinti M, Nasi M, Montagna JP, De Biasi S, Roat E, et al. Quercetin and cancer chemoprevention. Evid Based Complement Alternat Med. 2011;2011:591356

[7] Lam T K, Shao S, Zhao Y, et al. Influence of quercetin-rich food intake on microRNA expression in lung cancer tissues[J]. Cancer Epidemiology Biomarkers \& Prevention, 2012, 21(12): 2176-2184.

[8]Zhang W, Zhang F. Effects of quercetin on proliferation, apoptosis, adhesion and migration, and invasion of HeLa cells. Eur J Gynaecol Oncol. 2009;30(1):60-4.

[9]Aggarwal BB, Shishodia S. Molecular targets of dietary agents for prevention and therapy of cancer. Biochem Pharmacol. 2006;71(10):1397-421.

[10] Vásquez-Garzón V R, Macias-Pérez J R, Jiménez-García M N, et al. The chemopreventive capacity of quercetin to induce programmed cell death in hepatocarcinogenesis[J]. Toxicologic pathology, 2012: 0192623312467522..

[11] Maalik A, Khan F A, Mumtaz A, et al. Pharmacological Applications of Quercetin and its Derivatives: A Short Review[J]. Tropical Journal of Pharmaceutical Research, 2014, 13(9): 1561-1566. .

[12] Zhang X A, Zhang S, Yin Q, et al. Quercetin induces human colon cancer cells apoptosis by inhibiting the nuclear factor-kappa B Pathway[J]. Pharmacognosy magazine, 2015, 11(42): 404. 